\title{
Clinical implications of a possible role of vitamin D in multiple sclerosis
}

\author{
Charles Pierrot-Deseilligny
}

Received: 20 February 2009/Revised: 3 April 2009/Accepted: 7 April 2009/Published online: 28 April 2009

(C) The Author(s) 2009. This article is published with open access at Springerlink.com

\begin{abstract}
Hypovitaminosis D is currently one of the most studied environmental risk factors for multiple sclerosis (MS) and is potentially the most promising in terms of new clinical implications. These practical consequences, which could be applied to MS patients without further delay, constitute the main purpose of this review. Vitamin D is involved in a number of important general actions, which were not even suspected until quite recently. In particular, this vitamin could play an immunomodulatory role in the central nervous system. Many and varied arguments support a significant role for vitamin D in MS. In animal studies, vitamin D prevents and improves experimental autoimmune encephalomyelitis. Epidemiologically, latitude, past exposure to sun and the serum level of vitamin D influence the risk of MS, with, furthermore, significant links existing between these different factors. Clinically, most MS patients have low serum levels of vitamin D and are in a state of insufficiency or even deficiency compared to the international norm, which has been established on a metabolic basis. Large therapeutic trials using vitamin D are still lacking but the first results of phase I/II studies are promising. In the meantime, while awaiting the results of future therapeutic trials, it can no longer be ignored that many MS patients have a lack of vitamin $\mathrm{D}$, which could be detected by a serum titration and corrected using an appropriate vitamin D supplementation in order to restore their serum level to within the normal range. From a purely medical point of view, vitamin D supplementation appears
\end{abstract}

C. Pierrot-Deseilligny $(\square)$

Service de Neurologie 1, Hôpital de la Salpêtrière,

Assistance Publique, Hôpitaux de Paris, 47 bd de l'Hôpital,

75657 Paris Cedex 13, France

e-mail: cp.deseilligny@psl.aphp.fr;

cp.deseilligny@psl.ap-hop-paris.fr in this light to be unavoidable in order to improve the general state of these patients. Furthermore, it cannot currently be ruled out that this supplementation could also be neurologically beneficial.

Keywords Multiple sclerosis · Vitamin D

\section{Introduction}

Risk factors for MS are becoming clearer even if the mechanisms leading from these risk factors to the disease itself remain obscure. There are two main types of risk factors for MS, i.e. genetic and environmental, likely with complex interactions between them and effects which may be deleterious or protective, depending on the case [37]. Genetic risk factors are numerous [56, 99], but they are still relatively not well known and will not be dealt with here. Three environmental risk factors have recently emerged from the literature $[5-7,34,54,62,92,93]$-i.e. hypovitaminosis D, past infection with Epstein-Barr virus (EBV) and smoking - with effects that could be cumulative [46, 53]. In this review, we shall confine our analysis to hypovitaminosis $\mathrm{D}$, which is the risk factor currently the most promising in terms of immediate clinical implications.

Hypovitaminosis D has long been suspected of being a risk factor for MS but there has recently been a sharp increase of interest in this factor $[12,35,44,45,60,83$, 116]. The putative protective role of vitamin D in MS is based on a wide-ranging series of arguments (Fig. 1a-c). The first group of arguments exists outside, or indeed before, the disease, including physiological, metabolic, experimental and immunological factors, in addition to which there are epidemiological data on the effects of 
Fig. 1 Types of studies supporting a role of vitamin D in MS

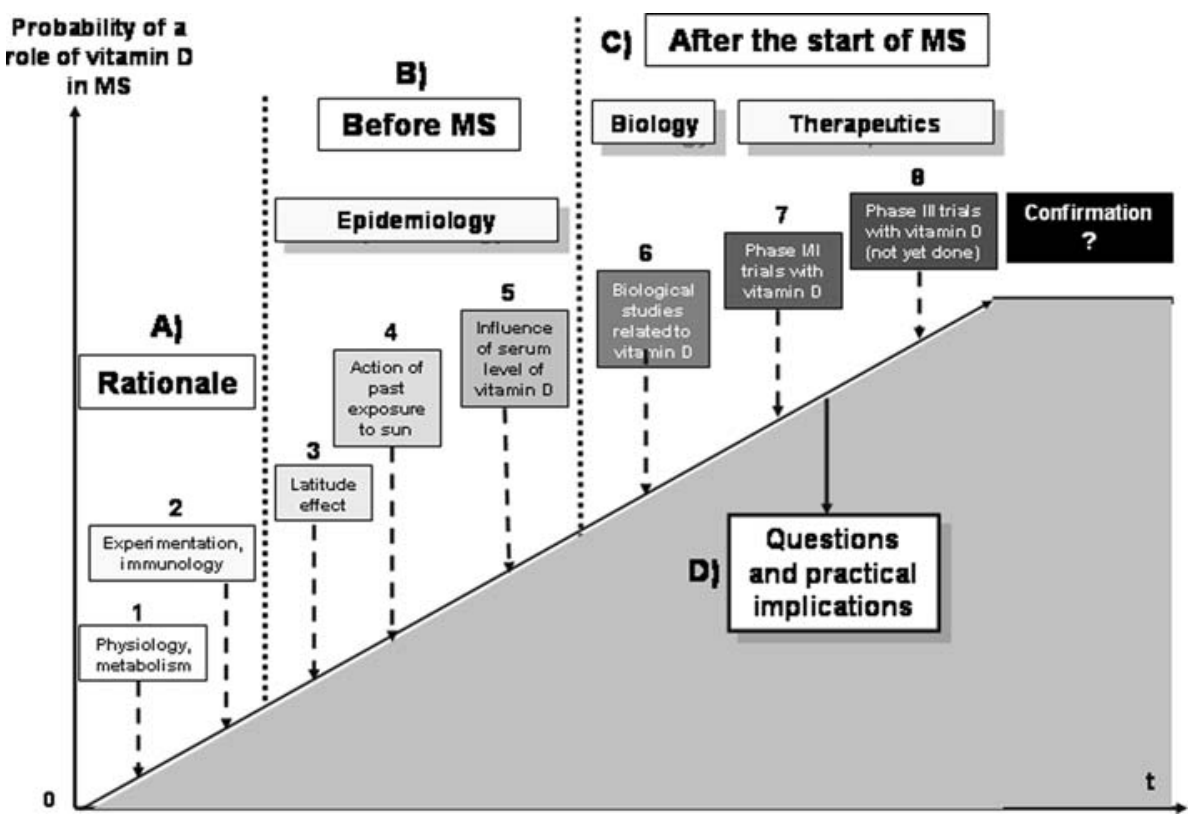

latitude, past exposure to sunlight and serum vitamin D levels on the risk of MS in the general population. The second group of arguments stems from data on MS patients derived from biological and therapeutic studies. We shall begin by looking at how these very diverse experimental and epidemiological arguments have progressively accumulated to strengthen the hypothesis that vitamin D plays a substantial protective role in MS. Then, even though there is no incontrovertible evidence from clinical studies to confirm that vitamin D can also have a curative effect, in the last chapter we shall propose the clinical applications that it would appear could be made available to MS patients without further delay (Fig. 1d). This paper is, to our knowledge, the first proposing such practical measures after the recent information reported on vitamin D in MS.

\section{Rationale}

\section{Physiological and metabolic basis}

Vitamin D is a steroidal hormone metabolised successively in the skin (by sunlight or ultraviolet B rays), the liver and the kidneys to the active metabolite 1.25-dihydroxyvitamin D3 (calcitriol), which has a half life of several hours. This metabolite is recognised by tissues containing specific vitamin $\mathrm{D}$ receptors which are present in many parts of the body: skin, bone, muscles, gonads, intestine, central nervous system (CNS), microglia, activated monocytes and B and $\mathrm{T}$ lymphocytes [23, 49-51, 69]. In addition to its well known action on calcium and phosphorus metabolism, vitamin D seems to have other important general effects, in particular anti-inflammatory and antiproliferative, and also modulatory effects on neurotrophins, growth factors and neurotransmitters in the CNS of mammals. Daily vitamin D requirements have recently been re-evaluated and are at least 2,000 IU/d, which is far higher than was thought necessary up until a few years ago [47, 52, 126, 127]. Vitamin D intake via (non-enriched) food is marginal in western diets, generally providing less than $100 \mathrm{IU} / \mathrm{d}$, which is far below the daily requirement, and even Scandinavian diets (rich in oily fish) scarcely exceed a few hundred IU/d [76]. Sunshine therefore remains the principal natural source of vitamin D, providing approximately $90 \%$ of requirements. Although sunbathing can provide $10,000-20,000 \mathrm{IU}$ in $15-30 \mathrm{~min}$, this supply disappears within a few weeks and cannot readily be replenished throughout the year except in tropical countries [52, 127]. Moreover, the elderly, regardless of origin, and darkskinned subjects, regardless of age, are less able to synthesise vitamin D than young, light-skinned subjects, who, if they protect themselves too much from the sun (by clothing or a sun block) may also rapidly find themselves in a state of vitamin D insufficiency. Lastly, women generally have lower serum levels than men [132, 133] and when pregnant or breast-feeding their vitamin $\mathrm{D}$ requirement is higher, which is, at the current time, rarely compensated for $[23,130]$.

The serum component of vitamin D usually measured is 25-hydroxyvitamin D (with a half life of several weeks), which is representative of an individual's overall vitamin D status [107, 134, 135]. The official international standard for serum 25-hydroxyvitamin D levels has been established on a physiological basis, mainly from calcium metabolism, since it is difficult to use control groups in the general population of temperate countries where most people could in fact be in a state of vitamin D insufficiency in the 
absolute, in particular in winter (see below). The internationally accepted norms fall between 75 and $200 \mathrm{nmol} / \mathrm{l}$, with insufficiency existing below $75 \mathrm{nmol} / 1$ and deficiency below $25 \mathrm{nmol} / 1$ [10, 25, 38, 52, 69, 96, 107, 125, 135]. The $75 \mathrm{nmol} / \mathrm{l}$ lower limit has not been arbitrarily established: it corresponds to the serum level below which the parathyroid hormone is stimulated by the lack of vitamin $\mathrm{D}$ and below which osteoporosis and pathological fractures become frequent. In fact, the current usual recommendations [38, 48, 52, 88, 107, 128, 135] suggest that a blood level of at least 90 or $100 \mathrm{nmol} / \mathrm{l}$ is needed first to optimise calcium and phosphorus metabolism (to reduce osteoporosis and to protect against pathological fractures), but also to improve the prevention of several major autoimmune diseases (diabetes, MS, lupus, rheumatoid arthritis etc.), three major cancers (colon, breast, prostate) and other common syndromes (asthenia, depression, hypertension) and infections in general, all of which are pathologies in which there has recently been an upsurge of studies implicating vitamin D. On these physiological grounds it can be deduced that vitamin $\mathrm{D}$ is most likely involved in a number of general regulatory activities, over and above calcium and phosphorus metabolism, and could have a notable immunological role to play, in particular within the CNS. One might also suspect that a vitamin D insufficiency or deficiency could exist whenever there is a shortage of sunlight, whether for an entire population-deprived of sunshine for reasons of climate-or for a given individual spending little or no time in the sun.

\section{Experimental and immunological studies}

There is a long-standing body of experimental evidenceconstantly being added to and now quite extensive-in favour of vitamin D having a marked role in experimental autoimmune encephalitis (EAE). Furthermore, many recent immunological studies suggest that this role could be antiinflammatory and immunomodulatory. Vitamin D clearly prevents the induction of EAE if administered before the triggering of the disease and noticeably improves clinical signs in affected mice if it is administered afterwards, thus having a significant effect that is both protective and curative $[9,11,14,15,17,19,32,67,78,79,82,84-86,90$, $102,108,110,121]$. This action is reported to be more marked in female mice than in male mice, due to the potentialisation of vitamin D by oestrogen [108]. It should be noted that a potentialisation of this type has also been reported in non-menopausal women [113, 123]. In EAE, vitamin D could have an anti-inflammatory effect [109] by reducing macrophages [84] and/or by regulating certain cytokines $[18,90,110]$, and/or a protective effect on myelin by activating oligodendrocytes [23] and/or an immunomodulatory effect on $\mathrm{T}$ lymphocytes by inhibiting
Th1 development and increasing Th 2 and $\operatorname{Tr}$ (regulatory T) lymphocyte restoration $[14,16,77,82,102]$. The latter effect (while not ruling out the others) currently seems the most well-founded, with vitamin D consequently having a mode of action that might be close to that of interferon $\beta$, the beneficial effect of which in EAE is indeed potentiated by vitamin D [122]. Lastly, in patients with MS, it has recently been suggested that vitamin $D$ also has a beneficial effect on Tr lymphocytes [24, 97]. Even if EAE is not exactly the same as MS, all these results, taken together, constitute a solid experimental basis that supports the existence of a marked immunological effect of vitamin D in this pathological field.

Epidemiological studies

There are now quite a number of epidemiological studies using a variety of different approaches suggesting a link between latitude, exposure to sun, vitamin D and MS (Fig. 2): (1) if we acknowledge that latitude influences the prevalence of MS, which is universally accepted, (2) if we note that latitude has an overall influence on the amount of sunlight in a given region, which is a geographical reality, (3) if we know that the level of exposure to sunlight directly affects the serum vitamin D level, which is physiologically indisputable, (4) if we add to these accepted facts that the latitude and the mean serum vitamin D level in the general population are correlated, (5) if we also consider that the level of exposure to sunlight does indeed influence the risk of MS, which has been widely reported, and, lastly, (6) if we accept that even the blood level of vitamin D can affect the risk of MS, which has also been reported, albeit in a rather limited fashion-all these links being reviewed in the following paragraphs-it is a reasonable hypothesis that latitude influences the risk of MS through the level of exposure to sunlight and the serum vitamin D level. While one can always argue that (a) there

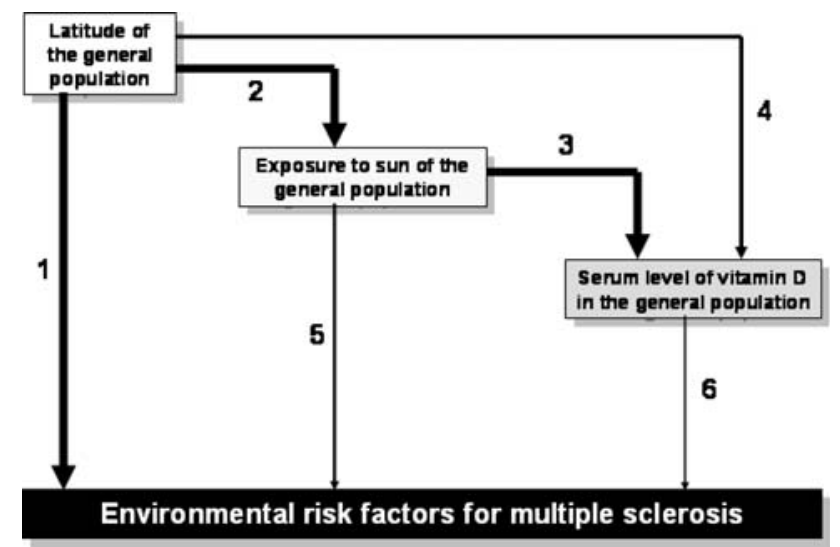

Fig. 2 Environmental epidemiological studies (numbers: see text) 
are too many uncertain conditions surrounding such a theory, that (b) the methodologies are not wholly satisfactory for this or that type of study, that (c) there seems to be insufficient evidence for this or that type of study, or else, for those studies that got past the previous criteria, that (d) there are also perhaps associated or confounding factors, the truth remains that it is currently not possible to put forward an alternative hypothesis that is as simple, global and logical as that of a protective role of vitamin D in MS to explain all these facts and results, an argument that is admittedly not proof in itself but nonetheless strongly supports the validity of such a hypothesis.

\section{Effect of latitude on the prevalence of $M S$}

Latitude has an undisputed effect on the prevalence of MS, which increases with distance from the equator, in both the northern and southern hemispheres, at a world level [31], at a continental level, as in Europe [65,91], as well as in very large countries, such as the USA [66] and Australia [117], and even in smaller countries, such as New Zealand [112] or France [30, 129]. In contrast, very low prevalences of MS are observed in tropical regions, for example in Ecuador [1], even though the protective effect of such regions appears to be nowadays slightly attenuated, likely due to changes in life style [3]. One can also see-at comparable latitudes - that the degree of sunlight in a given region or type of habitat (e.g., in Switzerland, in the mountains compared to lowland areas) is correlated with the prevalence of MS [64, 116, 119, 120]. It should also be noted that emigration after the age of 15-20 years has varying effects on immigrants depending on the direction of emigration: if it is from a region with a high prevalence of MS to a region of low prevalence, immigrants tend to acquire the low prevalence of the region to which they have emigrated (thereby losing the high risk of their region of origin), whereas in the opposite direction, when they move from a region with a low prevalence of MS to a region of high prevalence, they retain the low risk of their region of origin, at least for themselves, but not for their children, in whom one observes the same prevalence as that of the inhabitants of their host region [27-29, 31, 41, 66]. Only environmental (non-genetic) risk factors can explain these differences in prevalence between the new immigrants and their children. As for the difference in effect on the prevalence of MS according to the direction of emigration, this could be due to protective environmental factors of countries with a low prevalence of MS, which also happen to be those with (a) the most sun but also (b) the least 'hygiene' in its broadest sense, due to (1a) the sustained protective action of past exposure to sunlight (see below) received in these countries during childhood, which could persist after emigration to a country with less sun, and/or (1b) a subsequent, relatively protective effect of diverse infections contracted during childhood in countries with a low prevalence of MS (the so-called 'hygiene hypothesis'), and (2) the permanent and immediate protective effect of a country with a sunny climate if one has moved there before the normal age of onset of MS (i.e. in young adults) [5-7]. In sum, even if the effects of migration make it a little more difficult to interpret the role of latitude in MS risk, they do make it possible to suspect the involvement of several environmental risk factors-possibly including infectious factors-to explain these effects.

\section{Effect of latitude on serum vitamin D levels in the general population}

At this point in the discussion, it is appropriate to analyse the effects of latitude on vitamin D status in the general population. Numerous studies have shown that on average vitamin $\mathrm{D}$ levels are too low-in other words below the normal range, which has been established on a metabolic basis (see above) - in the adult population of all temperate countries where they have been studied: for example, in the USA, $74 \mathrm{nmol} / 1$ in a cohort from 1988 to 1994 ( $n=15,000)$ [133] declining to $60 \mathrm{nmol} / \mathrm{l}$ in a cohort from 2000 to $2004(n=18,558)$ [33, 71]; between 75 and $51 \mathrm{nmol} / 1$ in Australia, depending on the region ( $n=1,398)$ [119]; $51 \mathrm{nmol} / 1$ in the United Kingdom ( $n=7,437)$, with a north-south gradient [55]; $49 \mathrm{nmol} / \mathrm{l}$ in New Zealand $(n=2,900)$ [95]; $61 \mathrm{nmol} / \mathrm{l}$ in southern Canada $(n=188) \quad$ [98]; and $61 \mathrm{nmol} / 1$ in France ( $n=1,579$ ) [22]. It should be noted that the serum levels were determined in different seasons of the year in four of these studies and that on each occasion the levels in winter were 20-30 nmol/l lower than those in summer (Australia, United Kingdom, New Zealand and Canada). In France, the study related to nine different regions during the winter of 1994-1995. The lowest serum levels were observed in the north $(43 \mathrm{nmol} / \mathrm{l})$ and north-east $(53 \mathrm{nmol} / \mathrm{l})$ and the highest in the south $(81 \mathrm{nmol} / \mathrm{l})$ and south-west $(94 \mathrm{nmol} /$ 1), with significant correlations existing between these levels and both latitude $(P<0.01)$ and amount of sunshine $(P=0.003)$ [22]. In all these temperate countries, it was emphasised that such very low average levels of vitamin D raise serious public health issues and that there is an urgent need for national heath authorities to take preventive measures [38, 39], leading for example to vitamin D supplementation for all subjects in a state of insufficiency [20]. It should also be noted that rickets in very young children and osteomalacia in the elderly are nowadays generally well prevented in developed countries by paediatricians and geriatricians, who preventively treat their patients quasi systematically with vitamin $\mathrm{D}$, whereas, between these two extremities of life, little interest is shown in the 
vitamin D status of older children, adolescents and adults, probably on the assumption that in the great majority of cases it is normal; in fact, all recent epidemiological studies performed in medium or high latitude countries have shown that this is not at all the case (see above), which is potentially prejudicial for all people in these age-groups, not protected from hypovitaminosis $\mathrm{D}$ and its consequences in terms of increased risk of multiple, serious general affections, possibly including MS.

Looking now at a worldwide level, a correlation was found between latitude and the serum vitamin D level in Caucasian adult subjects in a recent meta-analysis covering 394 studies [40]. Generally speaking, Nordic countries have even lower vitamin $\mathrm{D}$ levels than those in temperate countries-e.g. $44 \mathrm{nmol} / \mathrm{l}$ in summer and $24 \mathrm{nmol} / \mathrm{l}$ in winter in Finland $(n=220$ young men) [115], and $29 \mathrm{nmol} / \mathrm{l}$ in winter in several countries of northern Europe ( $n=199$ adolescent girls) [4]—whereas tropical countries have far higher levels, e.g. $105 \mathrm{nmol} / \mathrm{l}$ in women and $168 \mathrm{nmol} / \mathrm{l}$ in men in Thailand ( $n=158$ adults) [21], and more than $100 \mathrm{nmol} / \mathrm{l}$ in several groups of children and adolescents in Brazil, including poorly nourished groups ( $n=638$ ) [68]. In another meta-analysis relating to Europe and Asia, it was stated that the factors affecting the serum vitamin $\mathrm{D}$ level in adults are age, sex, skin colour, type of clothing (wearing a veil leads almost systematically to insufficiency or deficiency), food (whether or not supplemented with vitamin D) and the degree of urbanisation [70]. Overall, the mean serum vitamin D level in the general population is therefore correlated with latitude and the amount of sunlight, whether one considers the world as a whole or one considers a relatively small country such as France. We can therefore see that there are links between latitude and the prevalence of MS on the one hand and between latitude, amount of sunlight and the serum vitamin D level in the general population on the other hand (Fig. 3). To complete this chain of cause and effect, we need to establish a link between the level of sunlight and the risk of MS, and then between the serum vitamin D level and the risk of MS. These will be dealt with in the following two paragraphs.

\section{Effect of exposure to sunlight on the risk of MS}

Based on a study of 136 MS patients and 272 control subjects in Tasmania, the risk of MS was found to be lower in those who in their childhood had been exposed to sunlight during their holidays and weekends than in those who had not benefited from such exposure $(P<0.01)$, a finding that was also correlated with the degree of actinic damage to their skin (an indicator of cumulative sun exposure, measured on the back of the hand) $(P<0.01)$ [118]. A similar result was found for the risk of CIS in Australia,

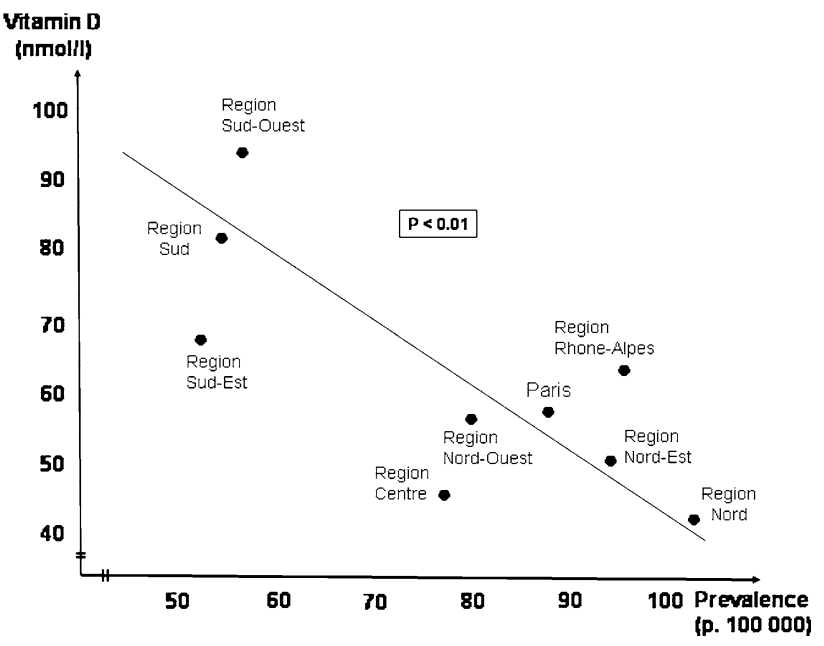

Fig. 3 Correlation (performed by the author of the present article) between the average serum levels of vitamin D in the general population of nine French regions and the MS prevalence in roughly analogous regions: data from Chapuy et al. [22] and Vukusic et al. [129], Pearson test $(r-0.790, P<0.01)$

which was correlated with past exposure to sun, actinic damage and latitude [72]. Inverse correlations between the risk of MS and past exposure to sunlight have also been reported in the USA [2], Norway [59] Canada [101] and Australia [26], with, furthermore, probable genetic regulation in the latter case. Lastly, in the USA, based on 79 monozygotic pairs of twins, one in each pair having MS and the other not and both twins being different in terms of exposure to the sun during their childhood (assessed on the basis of nine different activities implying sun exposure), it was shown that the twins who did not have MS were also those who had had significantly higher past exposure to the sun [57]. This result is particularly important because each pair of twins had the same genetic material and, apart from exposure to the sun, identical environmental constants (residence, food, etc.). In sum, the level of past exposure to the sun does indeed seem to play a role in the risk of MS.

\section{Effect of the serum vitamin D level in the general population on the risk of $M S$}

To date, only one study has directly analysed the risk of MS based on the serum level of 25-hydroxyvitamin D in normal subjects before MS occurred in some of them. The study, which appears methodologically sound, is therefore extremely important since it now indicates a direct link between the level of vitamin D circulating in the blood and the disease, without having to rely on the effect of latitude or sun exposure [81]. The study included 257 cases of MS that occurred in young American soldiers (148 white and 77 black), and 514 control subjects, who had given at least one serum sample before the onset of any neurological 
symptoms during their military service. For the white subjects, 5 subgroups were defined according to the serum level of vitamin D: the subgroup with the highest-in fact normal-levels of vitamin D (between 99 and $152 \mathrm{nmol} / \mathrm{l}$ ) had a significantly lower risk of MS than the subgroup with the lowest levels (between 15 and $63 \mathrm{nmol} / \mathrm{l})(P<0.01)$; for the less numerous black subjects, the results were not significant between the three defined subgroups, but the serum levels were much lower (not exceeding $99 \mathrm{nmol} / \mathrm{l}$ ) with, therefore, a much smaller range of serum levels between the different subgroups than for the white subjects. It was concluded in this study that a relatively high serum vitamin D level (though still within the normal range) is associated with a lower risk of MS in white subjects. On the basis of this study, Ascherio and Munger [6] have estimated that almost three-quarters of MS cases might be avoided if the serum levels of vitamin D were maintained above $100 \mathrm{nmol} / \mathrm{l}$ during childhood and adolescence in the general population. Furthermore, the fact that there is a correlation between the mean levels of vitamin D in the general population in regions of France and the prevalence of MS in these regions (Fig. 3) establishes an additional link between serum vitamin D level and the risk of MS. Lastly, we must also cite studies where the supposed high oral intake of vitamin $\mathrm{D}$, in the form of oily fish $[58,59]$ or vitamin supplements [80], decreased the risk of MS. The overall conclusion of these epidemiological studies is that it seems at least possible and already likely (see above) that there are links of causality between latitude, exposure to sun, serum vitamin D level and the risk of MS, in other words that the last link in this chain of influences, i.e. the one that is essential since it directly relates the organism to variations in the external environment, is vitamin D. This point of view, already proposed more than 35 years ago [35], now appears to be supported by numerous convergent experimental and epidemiological findings.

\section{Clinical studies}

Clinical studies on vitamin D in patients with MS have not yet achieved the same level of statistical power as experimental and epidemiological studies, but they are beginning to accumulate and, in the great majority of cases, their results are along the same lines, namely that vitamin D has a probable role in MS.

\section{Biological studies related to vitamin D in MS}

In a relatively old American study, it was shown that the mean level of 25-hydroxyvitamin $\mathrm{D}$ was very low (42 nmol/l) in 80 hospitalised female MS patients (mean EDSS: 7.2) [87], but the very lack of mobility of these patients (virtually no longer going outdoors) could in large part explain this result. Of far greater interest is a recent Finnish study on a group of 40 patients at the onset of MS (mean EDSS: 1.5) in whom serum levels were significantly reduced in summer $(55 \mathrm{nmol} / \mathrm{l})$ compared to a control group ( $80 \mathrm{nmol} / \mathrm{l})$ [105]. Both patients and control subjects had low levels in winter (between 40 and $50 \mathrm{nmol} / \mathrm{l}$ ), without any marked difference, but we may consider that such low levels in winter are abnormal and prejudicial to all. Furthermore, in three different studies, patients had significantly lower levels during relapses than at other times $[24,105,106]$. In an Irish study, no differences were observed between the serum levels of patients with MS and control subjects, but the two groups were recruited in winter, with serum levels that were slightly low (67 and $69 \mathrm{nmol} / \mathrm{l}$ ) compared to the normal range [8]. In several other studies, serum vitamin D levels in MS patients were significantly reduced when compared to control subjects $[24,42,73,120]$ or to internationally accepted norms [74], or an inverse correlation was found between vitamin D level and either the EDSS [63, 103] or the relapse rate [114]. Other studies raised the question of a genetic regulation of vitamin D metabolism in patients with MS [89, 104], in particular in the HLA system [94], and of an influence of a vitamin D receptor gene polymorphism on disability [75, 111]. Lastly, as an illustration of vitamin D level in MS, out of 167 consecutive outpatients with a relapsing-remitting form of MS referred to a Parisian hospital between June 2008 and February 2009, 83\% were found to have a vitamin D insufficiency (with levels of 25hydroxyvitamin D below $75 \mathrm{nmol} / \mathrm{l}$ ), with $17 \%$ in a state of deficiency $(<25 \mathrm{nmol} / \mathrm{l})$, and $95 \%$ did not reach the currently recommended level of $100 \mathrm{nmol} / \mathrm{l}$, with a general mean of $52 \mathrm{nmol} / \mathrm{l}$ (Fig. 4, unpublished personal data). These different studies, which of course need to be confirmed, nevertheless already strongly suggest that most patients with MS have serum vitamin D levels that are too low when compared to the current norms. It should also be added that a good proportion of MS patients with vitamin D insufficiency have little or no disability and that one can (1) neither attribute the vitamin D insufficiency to a reduced mobility in these patients, (2) nor roughly predict the vitamin D status of individuals on the basis of their disability. It is nevertheless true that disability, by reducing the opportunities for going outdoors, as well as systematically avoiding heat-and therefore the sun-in a good many symptomatic MS patients (able or disabled) [100] are factors that can exacerbate an initial hypovitaminosis D. Accordingly, although it may be still difficult to accept that a major and previously unsuspected problem of hypovitaminosis D exists in MS patients, it should nevertheless be realised that these patients are at least as lacking in vitamin $\mathrm{D}$ as the general population, and maybe even a little more, although this latter point requires further studies. 


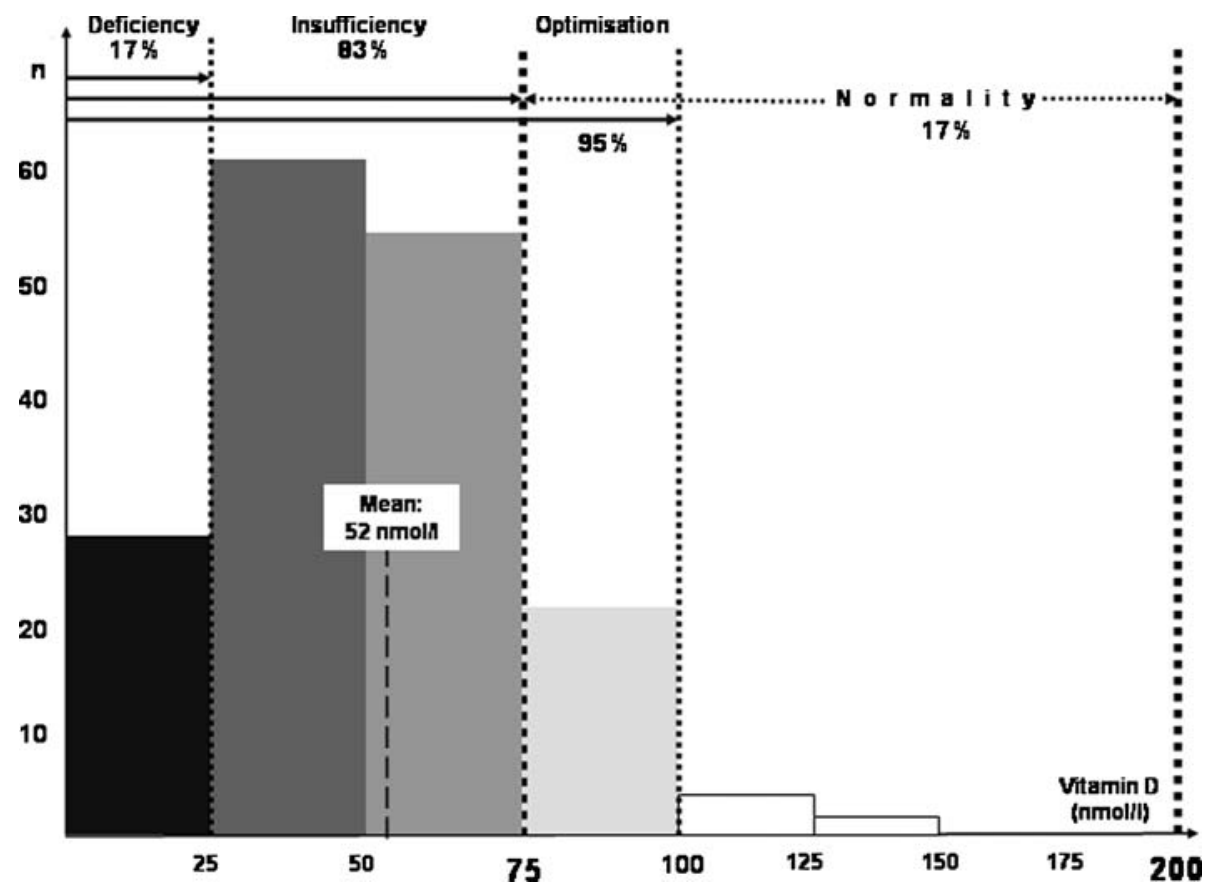

Fig. 4 Serum levels of 25-hydroxyvitamin D in a Paris cohort of patients with MS (unpublished personal data): 167 consecutive outpatients with a relapsing-remitting form referred to Salpêtrière hospital between June 2008 and February 2009, most of them already being treated with the usual preventive MS therapies (interferons $\beta$, glatiramer acetate or natalizumab), but none being supplemented with

\section{Effect of vitamin D treatment in MS}

Studies on the use of vitamin D in MS are still rare and limited in scope. After a two-year course of treatment with vitamin $\mathrm{D}(5,000 \mathrm{IU} / \mathrm{d}$ in the form of cod liver oil), 10 patients with MS had a $60 \%$ reduction in the predicted number of relapses, but there was no control group [36]. In another uncontrolled study, 15 patients who received $100 \mathrm{IU} / \mathrm{d}$ for 48 weeks experienced a $50 \%$ reduction in relapses [131]. In a study on 39 patients with MS (17 treated with 1,000 IU/d of vitamin D3 (cholecalciferol) for 6 months and 22 control subjects), the treated patients had a significantly increased level of TGF- $\beta 1$, an anti-inflammatory cytokine affected by vitamin D in EAE [73]. Lastly, a Canadian team recently demonstrated that the use of high doses of vitamin D3 (cholecalciferol, 14,000 IU/d) during a long period (6 months-1 year) did not induce hypercalcaemia or notable side-effects, despite serum vitamin D levels of nearly $400 \mathrm{nmol} / 1$ [61]. After 1 year of such treatment, a $41 \%$ reduction in the number of relapses and a significant improvement in EDSS was observed in the treated patients ( $n=25$ vs. 24 untreated patients) [13]. The results of these methodologically weak studies do not of course allow us to draw any definite conclusions. However, taking into account the full scientific context, they are encouraging and provide ample justification for much more vitamin $\mathrm{D}$ at the time of the titration; $118 \mathrm{~W}$ and $49 \mathrm{M}$; mean age: 38 years; mean EDSS: 2.5; mean annualized relapse rate: 0.45 ; mean duration of disease: 6.1 years. Note that the international norm for 25 hydroxyvitamin D serum level is between 75 and $200 \mathrm{nmol} / \mathrm{l}$, but that the recommended lower limit is nowadays close to $100 \mathrm{nmol} / \mathrm{l}$ (see text)

extensive therapeutic trials (phase II or phase III). The appropriate vitamin D doses will, however, have to be determined, since the daily dosages in the aforementioned four studies were 100, 1000, 5,000 and 14,000 IU/d, a situation that raises the perplexing question of the useful therapeutic dosage.

Questions and practical clinical approach to vitamin D in MS

While awaiting the results of future large-scale therapeutic studies using vitamin $\mathrm{D}$, which will take several years to complete, we can already put forward several questions on the subject of vitamin D in MS (Fig. 1). Does vitamin D have a protective role in MS? We can either reply straight away in the affirmative if we consider that the physiological and experimental arguments and the epidemiological studies have already provided a sufficient level of probability, or we can, rather, remain skeptical and wait for other, more convincing studies. Yet, a negative response to such a question would appear to be untenable in the light of the data already available. Does vitamin $\mathrm{D}$ have a role to play in influencing the progression of MS once the disease has started? The answer to this second question depends on the results of the clinical studies already undertaken in MS, which are still limited as regards serum vitamin D levels 
and remain in the embryonic state in terms of therapeutic applications. Consequently, if at present we do not wish to reply to this question in either the affirmative or the negative, we can remain in a state of expectation. However, the first two questions lead inevitably to a third question. Should the serum level in vitamin D of patients with MS be systematically tested? If the answer to the first two questions was not in the negative, the answer to this third question must inevitably be in the affirmative. In fact, it is no longer the specifically neurological-and still uncertain-aspect of these questions that is being raised here but rather a general and already far better documented medical issue. Indeed, multiple studies-even if we only take into account those that have actually been published-suggest that a majority of patients with MS have a vitamin D insufficiency, a good number of whom are even in a state of deficiency. Moreover, this insufficiency could be even slightly more marked than that already existing in the general population. From a purely medical point of view, we cannot ignore that a vitamin insufficiency or deficiency existing in the absolute is, at the very least, detrimental to the general health of these patients. This point should be considered by itself right now and uncoupled both from any possible, additional specific neurological aspects and from the more global problem of hypovitaminosis D existing in the general population, both questions which should and will be dealt with separately in the immediate future.

After the serum titration of vitamin D, it appears useful to supplement patients who are in a state of insufficiency [24]. This should involve MS patients at all stages of the disease, but could also include patients who are at the CIS stage or even before this stage (i.e. with 'pre-CIS', based solely on magnetic resonance imaging criteria), in an attempt also to achieve maximal possible protection of patients who are still at the very beginning of an abnormal inflammatory process. However, for all these patients with a lack of vitamin $\mathrm{D}$, the main aim of supplementation would, at present, be a general medical one, namely simply to increase serum concentrations to the currently recommended normal level, i.e. in the region of $100 \mathrm{nmol} / \mathrm{l}$ (see above): this would mean administering between 1,000 and 3,000 IU of vitamin D3 (cholecalciferol) on average per day (using either daily or monthly intakes), adjusted according to the initial serum concentration $[47,52,107,124,126,128]$. This measure should already improve the general health of patients with vitamin D insufficiency or deficiency by normalising calcium and phosphorus metabolism, but perhaps also by reducing asthenia, optimising muscle strength, reducing susceptibility to various infections, having a beneficial effect on thymic status, etc. Furthermore, it cannot currently be ruled out that relatively moderate doses of vitamin D-precisely such as those used to bring the serum level up to normality - can also have a favourable effect on the progression of the neurological disease itself, including at its earliest stages (CIS and pre-CIS). Lastly, it is important before starting the treatment to check that there is no hypercalcaemia (which may exceptionally be present) and after several months to monitor the serum vitamin $\mathrm{D}$ level and calcaemia, so that the daily dosage can be adjusted if necessary. There is no need to fear vitamin D intoxication-an unfounded myth - or hypercalcaemia during the treatment (1) if the patient has normal (or low) calcaemia before starting the treatment, (2) if one uses 25hydroxyvitamin D3 (cholecalciferol) and not 1,25-dihydroxyvitamin D3 (calcitriol), with, moreover, (3) doses of less than 10,000 IU/d [43, 124, 127]. This theoretical upper limit $(10,000 \mathrm{IU} / \mathrm{d})$ leaves a considerable safety margin if one uses at most a dose of 2,000 or $3,000 \mathrm{IU} / \mathrm{d}$ simply to normalise serum concentrations. Very longterm vitamin D treatment should be envisaged and, where low exposure to sunlight is a constant factor, maintained generally at the same doses, failing which the serum concentration will return to the insufficiency zone if the treatment is stopped or the dosage simply reduced. In sum, this treatment, which has become mandatory from a general medical point of view for MS patients with a proven lack of vitamin $\mathrm{D}$, can be given in addition to the other, main preventive therapies and is in fact simple, natural, safe and inexpensive. It could also be useful from a neurological perspective, for the overall progression of MS and for certain everyday symptoms.

\section{Conclusions}

Based on considerable physiological evidence, a large body of experimental findings, consistent epidemiological data and limited but promising clinical studies, the hypothesis that hypovitaminosis D is one of the environmental risk factors for MS has rapidly gained support and could soon be confirmed by more extensive clinical studies. Over and above its possible role in MS, hypovitaminosis D-due to its widespread distribution among the general population in countries with low levels of sunlight - now raises a crucial public health problem which must be solved if we are to achieve optimal prevention of a number of general affections that are common in these countries. Neurologists, like all medical practitioners, should be keenly aware of this problem, but those who are more particularly involved in caring for MS patients must be doubly receptive and rapidly preventive, since 'time is brain' is also applicable to MS. 
Open Access This article is distributed under the terms of the Creative Commons Attribution Noncommercial License which permits any noncommercial use, distribution, and reproduction in any medium, provided the original author(s) and source are credited.

\section{References}

1. Abad EP, Pérez M, Alarcon T, Castro E, Diaz F, Santibanez R (2008) Epidemiological evidence of multiple sclerosis in Ecuador. Mult Scler 14(Suppl 1):S55-S56

2. Acheson ED, Bachrach CA, Wright FM (1960) Some comments on the relationship of the distribution of multiple sclerosis to latitude, solar radiation and other variables. Acta Psychiatr Scand Suppl 35:37-42. doi:10.1111/j.1600-0447.1960. tb08674.x

3. Alonso A, Hernan MA (2008) Temporal trends in the incidence of multiple sclerosis: a systematic review. Neurology 7:129135. doi:10.1212/01.wnl.0000316802.35974.34

4. Andersen R, Molgaard C, Skovgaard LT, Brot C, Cashman KD, Chabros E et al (2005) Teenage girls and elderly women living in northern Europe have low winter vitamin D status. Eur J Clin Nutr 59:533-541. doi:10.1038/sj.ejcn.1602108

5. Ascherio A, Munger KL (2007) Environmental risk factors for multiple sclerosis. Part I: the role of infection. Ann Neurol 61:288-299. doi:10.1002/ana.21117

6. Ascherio A, Munger KL (2007) Environmental risk factors for multiple sclerosis. Part II: non-infectious factors. Ann Neurol 61:504-513. doi:10.1002/ana.21141

7. Ascherio A, Munger K (2008) Epidemiology of multiple sclerosis: from risk factors to prevention. Semin Neurol 28:17-28. doi:10.1055/s-2007-1019126

8. Barnes M, Bonham MP, Robson PJ, Strain JJ, Lowe-Strong AS, Eaton-Evans J et al (2007) Assessment of 25-hydroxyvitamin D and 1,25-dihydroxyvitamin D3 concentrations in male and female multiple sclerosis patients and control volunteers. Mult Scler 13:670-672. doi:10.1177/1352458506072666

9. Becklund BR, Hansen DW, Deluca HF (2009) Enhancement of 1,25-dihydroxyvitamin D3-mediated suppression of experimental autoimmune encephalomyelitis by calcitonin. Proc Natl Acad Sci USA 106(13):5276-5281

10. Bischoff-Ferrari HA, Giovannucci E, Willett WC, Dietrich T, Dawson-Hughes B (2006) Estimation of optimal serum concentrations of 25-hydroxyvitamin D for multiple health outcomes. Am J Clin Nutr 84:18-28

11. Branisteanu DD, Waer M, Sobis S, Marcelis S, Vandeputte M, Bouillon R (1995) Prevention of murine experimental allergic encephalomyelitis: cooperative effects of cyclosporine and 1 alpha, 25-(OH)2D3. J Neuroimmunol 61:151-160. doi:10.1016/ 0165-5728(95)00076-E

12. Brown SJ (2006) The role of vitamin D in multiple sclerosis. Ann Pharmacother 40:1158-1161. doi:10.1345/aph.1G513

13. Burton JM, Kimball S, Vieth R, Bar-Or A, Dosch HM, Thibault L et al (2008) A phase I/II dose-escalation trial of oral vitamin D3 with calcium supplementation in patients with multiple sclerosis. Mult Scler 14(Suppl 1):S34

14. Cantorna MT (2006) Vitamin D and its role in immunology: multiple sclerosis and inflammatory bowel disease. Prog Biophys Mol Biol 92:60-64. doi:10.1016/j.pbiomolbio.2006.02.020

15. Cantorna MT (2008) Vitamin D and multiple sclerosis: an update. Nutr Rev 66(10 Suppl):S135-S138

16. Cantorna MT, Mahon BD (2004) Mounting evidence for vitamin $\mathrm{D}$ as an environmental factor affecting autoimmune prevalence. Exp Biol Med 229:1136-1142
17. Cantorna MT, Hayes CE, DeLuca HF (1996) 1,25-dihydroxyvitamin D3 reversibly blocks the progression of encephalomyelitis, a model of multiple sclerosis. Proc Natl Acad Sci USA 93:78617864. doi:10.1073/pnas.93.15.7861

18. Cantorna MT, Woodward WD, Hayes CE, DeLuca HF (1998) 1,25-dihydroxyvitamin D3 is a positive regulator for the two anti-encephalitogenic cytokines TGF-beta 1 and IL-4. J Immunol 160:5314-5319

19. Cantorna MT, Humpal-Winter J, DeLuca HF (1999) Dietary calcium is a major factor in 1,25-dihydroxycholecalciferol suppression of experimental autoimmune encephalomyelitis in mice. J Nutr 129:1966-1971

20. Cavalier E, Denanaye P, Chapelle JP, Souberbielle JC (2009) Vitamin D: current status and perspectives. Clin Chem Lab Med 47:120-127. doi:10.1515/CCLM.2009.036

21. Chailurkit LO, Rajatanavin R, Teerarungsikul B, Ongphiphadhanakul B, Puavilai G (1996) Serum vitamin D, parathyroid hormone and biochemical markers of bone turnover in normal Thai subjects. J Med Assoc Thai 79:499-504

22. Chapuy MC, Preziosi P, Maamer M, Arnaud S, Galan P, Hercberg S, Meunier PJ (1996) Prevalence of vitamin D insufficiency in an adult normal population. Osteoporos Int 7:439443. doi: $10.1007 / \mathrm{s} 001980050030$

23. Chaudhuri A (2005) Why we should offer routine vitamin D supplementation in pregnancy and childhood to prevent multiple sclerosis. Med Hypotheses 64:608-618. doi:10.1016/j.mehy. 2004.06.022

24. Correale J, Ysrraelit MC, Gaitan MI (2009) Immunomodulatory effects of 1,25-dihydroxyvitamin D3 in multiple sclerosis. Brain [Epub ahead of print]

25. Dawson-Hughes B, Heaney RP, Holick MF, Lips P, Meunier PJ, Vieth R (2006) Estimates of optimal vitamin D status. Osteoporos Int 16:713-716. doi:10.1007/s00198-005-1867-7

26. Dwyer T, van der Mei I, Ponsonby AL, Taylor BV, Stankovich J, McKay JD et al (2008) Melanocortin 1 receptor genotype, past environmental sun exposure, and risk of multiple sclerosis. Neurology 7:583-589. doi:10.1212/01.wnl.0000323928.57408. 93

27. Elian M, Dean G (1987) Multiple sclerosis among the United Kingdom-born children of immigrants from the West Indies. J Neurol Neurosurg Psychiatry 50:327-332. doi:10.1136/jnnp. 50.3.327

28. Elian M, Dean G (1993) Motor neuron disease and multiple sclerosis among immigrants to England from the Indian subcontinent, the Caribbean and East and West Africa. J Neurol Neurosurg Psychiatry 56:454-457. doi:10.1136/jnnp.56.5.454

29. Elian M, Nightingale S, Dean G (1990) Multiple sclerosis among United Kingdom-born children of immigrants from the Indian subcontinent, Africa and the West Indies. J Neurol Neurosurg Psychiatry 53:906-911. doi:10.1136/jnnp.53.10.906

30. Fromont A, Adnet J, Clerc L, Bonithon Kopp C, Binquet C, Moreau T (2008) The French prevalence gradient of multiple sclerosis according to gender. Mult Scler 14(Suppl 1):S65

31. Gale CR, Martyn CN (1995) Migrant studies in multiple sclerosis. Prog Neurobiol 47:425-448. doi:10.1016/0301-0082 (95)00033-X

32. Garcion E, Sindji L, Nataf S, Brachet P, Darcy F, MonteroMenei CN (2003) Treatment of experimental autoimmune encephalomyelitis in rat by 1,25-hydroxyvitamin D3 leads to early effects within the central nervous system. Acta Neuropathol 105:438-448

33. Ginde AA, Liu MC, Camargo CA Jr (2009) Demographic differences and trends of vitamin D insufficiency in the US population, 1988-2004. Arch Intern Med 169:626-632. doi: 10.1001/archinternmed.2008.604 
34. Giovannoni G, Ebers G (2007) Multiple sclerosis: the environment and causation. Curr Opin Neurol 20:261-268. doi: 10.1097/WCO.0b013e32815610c2

35. Goldberg P (1974) Multiple sclerosis: vitamin D and calcium as environmental determinants of prevalence (a viewpoint). Part I: sunlight, dietary factors and epidemiology. Int J Environ Stud 6:19-27. doi:10.1080/00207237408709630

36. Goldberg P, Fleming MC, Picard EH (1986) Multiple sclerosis: decreased relapse rate through dietary supplementation with calcium, magnesium and vitamin D. Med Hypotheses 21:193200. doi:10.1016/0306-9877(86)90010-1

37. Goodin DS (2009) The causal cascade to multiple sclerosis: a model for pathogenesis. PLoS One 4:e4565. doi:10.1371/ journal.pone. 0004565

38. Grant WB, Holick MF (2005) Benefits and requirements of vitamin D for optimal health: a review. Altern Med Rev 10:94111

39. Grant WB, Cross HS, Garland CF, Gohram ED, Moan J, Peterlik L et al (2009) Estimated benefit of increased vitamin D status in reducing the economic burden of disease in Western Europe. Prog Biophys Mol Biol [Epub ahead of print]

40. Hagenau T, Vest R, Gissel TN, Poulsen CS, Erlandsen M, Mosekilde L et al (2009) Global vitamin D levels in relation to age, gender, skin pigmentation and latitude: an ecologic metaregression analysis. Osteoporos Int 20:133-140. doi:10.1007/ s00198-008-0626-y

41. Hammond SR, English DR, McLeod JG (2000) The age-range of risk of developing multiple sclerosis: evidence from a migrant population in Australia. Brain 123:968-974. doi:10.1093/brain/ 123.5.968

42. Hanwell HE, Vieth R, Bar-Or A, Sadovnick S, Arnold D, Banwell B et al (2008) Serum 25-hydroxyvitamin D status as a determinant of multiple sclerosis following an initial demyelinating event in children. Mult Scler 14(Suppl 1):S6. doi: $10.1177 / 1352458507079657$

43. Hathcock JN, Shao A, Vieth R, Heaney R (2007) Risk assessment for vitamin D. Am J Clin Nutr 85:6-18

44. Hawks CH (2005) Are multiple sclerosis patients risk-takers? QJM 98:895-911. doi:10.1093/qjmed/hci135

45. Hayes CE, Cantorna MT, De Luca HF (1997) Vitamin D and multiple sclerosis. Proc Soc Biol Med 216:21-27

46. Hayes CE, Donald Acheson E (2008) A unifying multiple sclerosis etiology linking virus infection, sunlight, and vitamin D, through viral interleukin-10. Med Hypotheses 71:85-90. doi: 10.1016/j.mehy.2008.01.031

47. Heaney RP, Davies KM, Chen TC, Holick MF, Bager-Lux J (2003) Human serum 25-hydroxycholecalciferol response to extended oral dosing with cholecalciferol. Am J Clin Nutr 77:204-210

48. Holick MF (2004) Sunlight and vitamin D for bone health and prevention of autoimmune diseases, cancers, and cardiovascular disease. Am J Clin Nutr 80(6 suppl):1678S-1688S

49. Holick MF (2005) The vitamin D epidemic and its health consequences. J Nutr 135:2739S-2748S

50. Holick MF (2008) Vitamin D: a D-lightful health perspective. Nutr Rev 66(10 Suppl 2):S182-S194. doi:10.1111/j.1753-4887. 2008.00104.x

51. Holick MF (2008) The vitamin D deficiency pandemic and consequences for non-skeletal health: mechanisms of action. Mol Aspects Med 29:361-368. doi:10.1016/j.mam.2008.08.008

52. Hollis BW (2005) Circulating 25-hydroxyvitamin D levels indicative of vitamin D sufficiency: implications for establishing a new effective dietary intake recommendation for vitamin D. J Nutr 135:317-322

53. Holmoy T (2008) Vitamin D status modulates the immune response to Epstein-Barr virus: synergistic effect of risk factors in multiple sclerosis. Med Hypotheses 70:66-69. doi:10.1016/j. mehy.2007.04.030

54. Holmoy T, Hestvik AL (2008) Multiple sclerosis: immunopathogenesis and controversies in defining the cause. Curr Opin Infect Dis 21:271-278. doi:10.1097/QCO.0b013e3282f88b48

55. Hyppönen E, Power C (2007) Hypovitaminosis D in British adults at age $45 \mathrm{y}$ : nationwide cohort study of dietary and lifestyle predictors. Am J Clin Nutr 85:860-868

56. International Multiple Sclerosis Genetics Consortium (2008) The expanding genetic overlap between multiple sclerosis and type I diabetes. Genes Immun 10(1):11-14

57. Islam T, Gauderman WJ, Cozen W, Mack TM (2007) Childhood sun exposure influences risk of multiple sclerosis in monozygotic twins. Neurology 69:381-388. doi:10.1212/01.wnl. 0000268266.50850.48

58. Kampman MT, Brustad M (2008) Vitamin D: a candidate for the environmental effect in multiple sclerosis-observations from Norway. Neuroepidemiology 30:140-146. doi:10.1159/ 000122330

59. Kampman MT, Wilsgaard T, Mellgren SI (2007) Outdoor activities and diet in childhood and adolescence relate to MS risk above the Arctic Circle. J Neurol 254:471-477. doi:10.1007/s00415-006-0395-5

60. Kantarci O, Wingerchuk O (2006) Epidemiology and natural history of multiple sclerosis: new insights. Curr Opin Neurol 19:248-254. doi:10.1097/01.wco.0000227033.47458.82

61. Kimball SM, Ursell MR, O'Connor P, Vieth R (2007) Safety of vitamin D3 in adults with multiple sclerosis. Am J Clin Nutr 86:645-651

62. Kimlin MG (2008) Geographic location of vitamin D synthesis. Mol Aspects Med 29:453-461. doi:10.1016/j.mam.2008.08.005

63. Kragt J, van Amerogen B, Killestein J, Dijkstra CD, Vitdehaag BMJ, Polman CH et al (2009) Higher levels of 25-hydroxyvitamin D are associated with a lower incidence of multiple sclerosis only in women. Mult Scler 15:9-15. doi:10.1177/ 1352458508095920

64. Kurtzke JF (1967) On the fine structure of the distribution of multiple sclerosis. Acta Neurol Scand 43:257-282. doi:10.1111/ j.1600-0404.1967.tb05733.x

65. Kurtzke JF (1995) MS epidemiology world wide. One view of current status. Acta Neurol Scand 161(Suppl):23-33. doi:10.1111/j.1600-0404.1995.tb05853.x

66. Kurtzke JF, Beebe JW, Norman JE (1985) Epidemiology of multiple sclerosis in US veterans: III; Migration and the risk of MS. Neurology 35:672-678

67. Lemire JM, Archer DC (1991) 1,25-dihydroxyvitamin D3 prevents the in vivo induction of murine experimental autoimmune encephalomyelitis. J Clin Invest 87:1103-1107. doi:10.1172/ JCI115072

68. Linhares ER, Jones DA, Round JM, Edwards RH (1984) Effect of nutrition on vitamin D status: studies on healthy and poorly nourished Brazilian children. Am J Clin Nutr 39:625-630

69. Lips P (2006) Vitamin D physiology. Prog Biophys Mol Biol 92:4-8. doi:10.1016/j.pbiomolbio.2006.02.016

70. Lips P (2007) Vitamin D status and nutrition in Europe and Asia. J Steroid Biochem Mol Biol 103:620-625. doi:10.1016/ j.jsbmb.2006.12.076

71. Looker AC, Pfeiffer CM, Lacher DA, Schleicher RL, Picciano MF, Yetley EA (2008) Serum 25-dihydroxyvitamin D status in the US population: 1988-1994 compared with 2000-2004. Am J Clin Nutr 88:1519-1527. doi:10.3945/ajen.2008.26182

72. Lucas R, Taylor BV, Ponsonby A-L, Chapman P, Coulthard $A$, Dear K et al (2008) Latitudinal variation in incidence of first demyelinating events: descriptive analyses of case participants in the Ausimmune Study. Mult Scler 14(Suppl 1):S190-S191 
73. Mahon BD, Gordon SA, Cruz J, Cosman F, Cantorna MT (2003) Cytokine profile in patients with multiple sclerosis following vitamin D supplementation. J Neuroimmunol 134:128-132. doi:10.1016/S0165-5728(02)00396-X

74. Makhani N, Magalaes S, Fairbrother C, Banwell B (2008) Vitamin D status in children with multiple sclerosis. Mult Scler 14(Suppl 1):S191

75. Mamutse G, Woolmore J, Pye E, Partridge J, Boggild M, Young $\mathrm{C}$ et al (2008) Vitamin D receptor gene polymorphism is associated with reduced disability in multiple sclerosis. Mult Scler 14:1280-1283. doi:10.1177/1352458508094643

76. Mark BL, Carson JA (2006) Vitamin D and autoimmune disease-implications for practice from multiple sclerosis literature. J Am Diet Assoc 106:418-424. doi:10.1016/j.jada. 2005.12.009

77. Mattner FS, Smiroldo S, Gabliati F, Muller M, Di Lucia P, Poliani PL et al (2000) Inhibition of Th1 development and treatment of chronic-relapsing experimental allergic encephalomyelitis by a non-hypercalcemic analogue of 1,25-dihydroxyvitamin D3. Eur J Neuroimmunol 30:498-508. doi: 10.1002/1521-4141(200002)30:2<498::AID-IMMU498>3.0.CO; 2-Q

78. Meehan F, DeLuca HF (2002) The vitamin D receptor is essential for 1alpha, 25-dihydroxyvitamin $\mathrm{D}(3)$ to suppress experimental autoimmune encephalomyelitis in mice. Arch Biochem Biophys 408:200-204. doi:10.1016/S0003-9861(02) 00580-5

79. Meehan F, DeLuca HF (2002) CD8+ T cells are not necessary for $1 \alpha, 25$-dihydroxyvitamin D3 to suppress experimental autoimmune encephalomyelitis. Proc Natl Acad Sci USA 99:5557-5560

80. Munger KL, Zhang SM, O'Reilly E, Hernan MA, Olek MJ, Willet WC, Ascherio A (2004) Vitamin D intake and incidence of multiple sclerosis. Neurology 62:60-65

81. Munger KL, Levin LI, Hollis BW, Howard NS, Ascherio A (2006) Serum 25-hydroxyvitamin D levels and risk of multiple sclerosis. JAMA 296:2832-2838. doi: 10.1001/jama.296.23.2832

82. Muthian G, Raikvar HP, Rajasingh J, Brigh JJ (2006) 1,25dihydroxyvitamin D3 modulates JAK-STAT pathway in IL-12/ IFNgamma axis leading to Th1 response in experimental allergic encephalomyelitis. J Neurosci Res 83:1299-1309. doi:10.1002/jnr.20826

83. Namaka M, Crook A, Doupe A, Kler K, Vasconcelos M, Klowak $M$ et al (2008) Examining the evidence: complementary adjunctive therapies for multiple sclerosis. Neurol Res 30:710 719. doi: $10.1179 / 174313208 \times 325038$

84. Nashold FE, Miller DJ, Hayes DE (2000) 1,25-dihydroxyvitamin D3 treatment decreases macrophage accumulation of mice with experimental autoimmune encephalomyelitis. J Neuroimmunol 103:171-179. doi:10.1016/S0165-5728(99)00247-7

85. Nashold FE, Hoag KA, Goverman J, Hayes CE (2001) Rag-1dependent cells are necessary for 1,25-dihydroxyvitamin D3 prevention of experimental autoimmune encephalomyelitis. J Neuroimmunol 119:16-29. doi:10.1016/S0165-5728(01) 00360-5

86. Nataf S, Garcio E, Darcy F, Chabannes D, Muller JY, Brachet P et al (1996) 1,25-dihydroxyvitamin D3 exerts regional effects in the central nervous system during experimental allergic encephalomyelitis. J Neuropathol Exp Neurol 55:904-914

87. Nieves J, Cosman F, Herbert J, Shen V, Lindsay R (1994) High prevalence of vitamin $\mathrm{D}$ deficiency and reduced bone mass in multiple sclerosis. Neurology 44:1687-1692

88. Niino M, Fukazawa T, Kikuchi S, Sasaki H (2008) Therapeutic potential of vitamin D for multiple sclerosis. Curr Med Chem 15:499-505. doi:10.2174/092986708783503159
89. Orton SM, Morris AP, Herrera BM, Ramagopalan SV, Lincoln MR, Chao MJ et al (2008) Evidence for genetic regulation of vitamin D status in twins in multiple sclerosis. Am J Clin Nutr 88:441-447

90. Pedersen LB, Nashold FE, Spach KM, Hayes CE (2007) 1,25dihydroxyvitamin D3 reverses experimental autoimmune encephalomyelitis by inhibiting chemokines synthesis and monocyte trafficking. J Neurosci Res 85:2480-2490. doi: 10.1002/jnr.21382

91. Pugliatti M, Rosati G, Carton H, Riise T, Drulovic J, Vécsei L, Milanov I (2006) The epidemiology of multiple sclerosis in Europe. Eur J Neurol 13:700-722. doi:10.1111/j.1468-1331. 2006.01342.x

92. Pugliatti M, Harbo HF, Holmoy T, Kampman MT, Myhr KM, Riise T, Wolfson T (2008) Environmental risk factors in multiple sclerosis. Acta Neurol Scand Suppl 188:34-40. doi: 10.1111/j.1600-0404.2008.01029.x

93. Raghuwanshi A, Joshi SS, Christakos S (2008) Vitamin D and multiple sclerosis. J Cell Biochem 105:338-343. doi:10.1002/ jcb. 21858

94. Ramagopalan SG, Maugeri NJ, Handunnetthi L, Lincoln MR, Orton SM, Dyment DA et al (2009) Expression of multiple sclerosis-associated MHC class II Allele HLA-DBR1*1501 is regulated by vitamin D. PLoS Genet 5:e1000369. doi:10.1371/ journal.pgen.1000369

95. Rockell JE, Skeaff CM, Williams SM, Green TJ (2006) Serum 25-hydroxyvitamin D concentrations of New Zealanders aged 15 years and older. Osteoporos Int 17:1382-1389. doi:10.1007/ s00198-006-0118-x

96. Roux C, Bischoff-Ferrari HA, Papapoulos SE, de Papp AE, West JA, Bouillon R (2008) New insights into the role of vitamin $\mathrm{D}$ and calcium in osteoporosis management: an expert roundtable discussion. Curr Med Res Opin 24:1363-1370. doi:10.1185/030079908X301857

97. Royal W, Mia Y, Li H (2008) Vitamins D and A levels and regularity $\mathrm{T}$ cells in patients with multiple sclerosis. Mult Scler 14(Suppl 1):S242

98. Rucker D, Allan JA, Fick GH, Hanley DA (2002) Vitamin D insufficiency in a population of healthy western Canadians. CMAJ 166:1517-1524

99. Sawcer S, Compston A (2006) Multiple sclerosis: light at the end of the tunnel. Eur J Hum Genet 14:257-258. doi:10.1038/ sj.ejhg.5201561

100. Simmons RD, Ponsonby AL, van der Mei IA, Sheridan P (2004) What affects your MS? Responses to an anonymous Internetbased epidemiological study. Mult Scler 10:202-211. doi:10.1191/1352458504ms1006oa

101. Sloka JS, Pryse-Phillips WE, Stefanelli M (2008) The relation of ultraviolet radiation and multiple sclerosis in Newfoundland. Can J Neurol Sci 35:69-74

102. Smolders J, Damoiseaux J, Menheere P, Hupperts R (2008) Vitamin $\mathrm{D}$ as an immune modulator in multiple sclerosis, a review. J Neuroimmunol 194:7-17. doi:10.1016/j.jneuroim. 2007.11.014

103. Smolders J, Menheere P, Kessels A, Damoiseaux J, Hupperts R (2008) Association of vitamin D metabolite levels with relapse rate and disability in multiple sclerosis. Mult Scler 14:1220 1224. doi: $10.1177 / 1352458508094399$

104. Smolders J, Damoiseaux J, Menheere P, Trevaert JW, Hupperts R (2009) Fok-I vitamin D receptor gene polymorphism (rs10735810) and vitamin D metabolism in multiple sclerosis. J Neuroimmunol 207(1-2):117-121

105. Soilu-Hänninen M, Airas L, Monnonen I, Heikkilä A, Viljanen $\mathrm{N}$, Hänninen A (2005) 25-Hydroxyvitamin D levels in serum at the onset of multiple sclerosis. Mult Scler 11:266-271. doi:10.1191/1352458505ms1157oa 
106. Soilu-Hänninen M, Laaksonen M, Laitinen I, Erälinna J-P, Lillius E-M, Mononen I (2008) A longitudinal study of serum 25-hydroxyvitamin D and intact parathyroid hormone levels indicate the importance of vitamin D and calcium homeostasis regulation in multiple sclerosis. J Neurol Neurosurg Psychiatry 79:152-157. doi:10.1136/jnnp.2006.105320

107. Souberbielle JC, Prié D, Courbebaisse M, Friedlander G, Houillier P, Maruani G et al (2008) Actualité sur les effets de la vitamine D et l'évaluation du statut vitaminique D. Ann Endocrinol (Paris) 69:501-510. doi:10.1016/j.ando.2008.07.010

108. Spach KM, Hayes CE (2005) Vitamin D3 confers protection from autoimmune encephalomyelitis only in female mice. $\mathrm{J}$ Immunol 175:4119-4126

109. Spach KM, Pedersen LB, Nashold FE, Kayo T, Yandell BS, Prolla TA, Hayes CE (2004) Gene expression analysis suggests that 1,25-dihydroxyvitamin D3 reverses experimental autoimmune encephalomyelitis by stimulating inflammatory cell apoptosis. Physiol Genomics 18:141-151. doi:10.1152/ physiolgenomics.00003.2004

110. Spach KM, Nashold FE, Dittel BN, Hayes CE (2006) IL-10 signalling is essential for 1,25-dihydroxyvitamin d3-mediated inhibition of experimental autoimmune encephalomyelitis. J Immunol 177:6030-6037

111. Tajouri L, Ovcaric M, Curtain R, Johnson MP, Griffiths LR, Csurhes P et al (2005) Variation in vitamin D receptor gene is associated with multiple sclerosis in an Australian population. J Neurogenet 19:25-38. doi:10.1080/01677060590949692

112. Taylor BV, Richardson A, Mason DF, Wlloughby E, Abenethy D, Sabel C (2008) Prevalence of multiple sclerosis in New Zealand. Mult Scler 14(Suppl 1):S202

113. Tjellesen L, Christiansen C, Hummer L, Larsen NE (1983) Unchanged biochemical indices of bone turnover despite fluctuations in 1,25-dihydroxyvitamin D during the menstrual cycle. Acta Endocrinol (Copenh) 102:476-480

114. Tremlett H, van der Mei IA, Pittas F, Blizzard L, Paley G, Mesaros D et al (2008) Monthly ambient sunlight, infections and relapse rates in multiple sclerosis. Neuroepidemiology 3:271279. doi:10.1159/000166602

115. Välimäki VV, Alfthan H, Lehmuskallio E, Löyttyniemi E, Petterson K, Stenman UH et al (2004) Vitamin D status as a determinant of peak bone mass in young Finnish men. J Clin Endocrinol Metab 89:76-80. doi:10.1210/jc.2003-030817

116. VanAmerogen BM, Dijkstra CD, Lips P, Polman CH (2004) Multiple sclerosis and vitamin D: an update. Eur J Nutr 58:1095-1109. doi:10.1038/sj.ejcn.1601952

117. Van der Mei IA, Ponsonby AL, Blizzard L, Dwyer T (2001) Regional variation in multiple sclerosis prevalence in Australia and its association with ambient ultraviolet radiation. Neuroepidemiology 20:168-174. doi:10.1159/000054783

118. Van der Mei IAF, Ponsonby AL, Dwyer T, Blizzard L, Simmons R, Taylor BV et al (2003) Past exposure to sun, skin phenotype, and risk of multiple sclerosis: case-control study. BMJ 327:1-6. doi: $10.1136 / \mathrm{bmj} .327 .7410 .316$

119. Van der Mei IA, Ponsonby AL, Engelsen O, Pasco JA, McGrath JJ, Eyles DW et al (2007) The high prevalence of vitamin D insufficiency across Australian population is only partly explained by season and latitude. Environ Health Perspect 115:1132-1139
120. Van der Mei IA, Ponsonby AL, Dwyer T, Blizzard L, Taylor BV, Kilpatrick T et al (2007) Vitamin D levels in people with multiple sclerosis and community controls in Tasmania, Australia. J Neurol 254:581-590. doi:10.1007/s00415-006-0315-8

121. Van Etten E, Branisteanu DD, Overberg L, Bouillon R, Verstuyf A, Mathieu $C$ et al (2003) Combination of a 1,25-dihydroxyvitamin D3 analog and a bisphosphonate prevents experimental autoimmune encephalomyelitis and preserves bone. Bone 32:397-404. doi:10.1016/S8756-3282(03)00030-9

122. Van Etten E, Gysemans C, Branisteanu DD, Verstuyf A, Bouillon R, Overbergh L, Mathieu C (2007) Novel insights in the immune function of the vitamin D system: synergism with interferon-beta. J Steroid Biochem Mol Biol 103:546-551. doi:10.1016/j.jsbmb.2006.12.094

123. Van Hoof HJ, van der Mooren MJ, Swinkels LM, Sweep CJ, Merkus JM, Benraad TJ (1999) Female sex hormone therapy increases serum free 1,25-dihydroxyvitamin D3: a 1-year prospective study. Clin Endocrinol (Oxf) 50:511-516. doi:10.1046/ j.1365-2265.1999.00693.x

124. Vieth R (1999) Vitamin D supplementation, 25-hydroxyvitamin D concentrations, and safety. Am J Clin Nutr 69:842-849

125. Vieth R (2005) The role of vitamin D in the prevention of osteoporosis. Ann Med 37:278-285. doi:10.1080/ 07853890510007313

126. Vieth R (2006) What is the optimal vitamin D status for health? Prog Biophys Mol Biol 92:26-32. doi:10.1016/j.pbiomolbio. 2006.02.003

127. Vieth R (2007) Vitamin D toxicity, policy, and science. J Bone Miner Res 22(Suppl 2):V64-V68. doi:10.1359/jbmr.07s221

128. Vieth R, Bischoff-Ferrari H, Boucher BJ, Dawson-Hughes B, Garland CF, Heaney RP et al (2007) The urgent need to recommend an intake of vitamin D that is effective. Am J Clin Nutr 85:649-650

129. Vukusic S, Van Bokstael V, Gosselin S, Confavreux C (2003) Regional variations of multiple sclerosis prevalence in French farmers. J Neurol Neurosurg Psychiatry 78:707-709. doi: 10.1136/jnnp.2006.101196

130. Wagner CL, Taylor SN, Hollis BW (2008) Does vitamin D make the world go 'round'? Breastfeed Med 3:239-250. doi: 10.1089/bfm.2008.9984

131. Wingerchuck DM, Lesaux J, Rice JP, Kremenchtzky M, Ebers GC (2005) A pilot study of oral calcitriol (1,25-dihydroxyvitamin D3) for relapsing-remitting multiple sclerosis. J Neurol Neurosurg Psychiatry 76:1294-1296. doi:10.1136/jnnp.2004. 056499

132. Yetley EA (2008) Assessing the vitamin D status in the US population. Am J Clin Nutr 88:558S-5564S

133. Zadshir A, Tareen N, Pan D, Norris K, Martins D (2005) The prevalence of hypovitaminosis D among US adults: data from the NHANES III. Ethn Dis 15:S5 97-101

134. Zerwekh JE (2008) Blood biomarkers on vitamin D status. Am J Clin Nutr 87:1087S-1091S

135. Zittermann A (2003) Vitamin D in preventive medicine: are we ignoring the evidence? Br J Nutr 89:552-572. doi:10.1079/ BJN2003837 